\title{
I forgot that there was a huge kid on second: the importance of body protective play for ADHD child and teen athletes
}

Volume 9 Issue I - 2018

\section{Opinion}

As a 12 year old boy with ADHD (Attention Deficit Hyperactivity Disorder) I have been injured more times than most other kids without ADHD. Most recently, I suffered a serious concussion while playing a casual game of football during my afterschool program. I dove to catch a ball without considering my surroundings. This is one thing that ADHD does to a kid: he focuses on one thing, kind of like blinders on a horse. My concussion sidelined me for two months and as soon as I was cleared for play I had another collision while playing third base for my little league team. A massive 12year old kid barreled into me, hyper-extending my knee. As I write this story, I am into my second week wearing a big brace. It never occurred to me to protect my body as I readied myself to make a play and knew that my large opponent was waiting on second to advance to my base.

Following my second injury, I met with my psychologist and he opened my eyes to the common pattern of ADHD kid and teen athletes not looking out to protect their bodies while competing. Dr Richfield said that I needed to learn how to compete with Body Protective Play. He told me that he coined this term to emphasize the need for kids to think about their own safety when playing contact sports. It means that at any time during competition a player can put his body into a dangerous position or place and suffer injury that takes them out of playing sports for a long time. I know it because it has happened to me too many times.

Body Protective Play is more than just actions you can take during competition, like moving away from third base when the runner is coming your way! It's a way of thinking. It's like mapping out the possible dangers, whether it is your opponents or the playing field or something else, and keeping that map in your mind while you are playing your chosen sport. But it also means that you have to think ahead and not just blindly run on the field and hope for the best! Thinking ahead means that you have to consider how fast a pitcher throws the ball, and how much he is known to hit batters, or to take note of any really big kids on the other team, or if you know something is wrong with the field you can make sure to avoid that spot. For example, my Little League field has a small ditch in center field that could cause you to twist your ankle. In short, you need to check your surroundings when you arrive at the field but also prepare yourself to take safety steps during competition so that you

\author{
Steven Richfield \\ Clinical Psychologist, Philadelphia, USA
}

Correspondence: Steven Richfield, Clinical Psychologist,
Philadelphia, USA, Tel 6I0-238-4450, Email director@parentcoachcards.com

Received: April 30, 2017| Published: January 04, 2018

don't sacrifice your bodily safety. Once the game begins, make sure the hyper focus blinders don't go on and remind yourself, "My body is more important than making a play!"

Another helpful idea to make sure you are playing your sport with Body Protective thinking is to ask your parents to video tape some of the game when you are on the field. Later, you and your parent can review the tape and see how well you protected your body while playing. Examine the film from the standpoint of whether you watched out for yourself or you put yourself in some unnecessary danger. Talk to your parents about what you notice and try to be open to what your parents suggest, even though that can be hard to do sometimes. Peter Iannacone is a 6th grader at Springford Middle School and a multisport athlete.

\section{Acknowledgements}

None.

\section{Conflict of interest}

Author declares there are no conflicts of interest.

\section{Funding}

None. 